\title{
The Cultural Meaning of the Wonosobo Social Community in Agricultural Spells
}

\author{
Ery Agus Kurnianto ${ }^{1}$, Yulianeta ${ }^{2}$, Mochamad Fikri $^{3}$, Inni Inayati Istiana ${ }^{4}$ \\ \{eratomainaka@gmail.com¹, mochammad.fikri@kemdikbud.go.id ${ }^{3}$ \} \\ Balai Bahasa Provinsi Jawa Tengah,Elang Raya Street 1, Mangunharjo, Tembalang, \\ Semarang, Central Java, Indonesia ${ }^{1,3,4}$, Universitas Pendidikan Indonesia \\ Dr. Setiabudi Street 229, Bandung, West Java, Indonesia ${ }^{2}$
}

\begin{abstract}
The spells or mantra and sajen consist of cultural content that reflects the characteristics of the Selokromo, Wonosobo community in carrying out farming activities. This study described the cultural meanings represented in the spells or mantra and sajen. This article was the explanatory one. The results of the interpretation were associated with the lifestyle, habits, and culture of the Selokromo community. The results of the interpretation had an educational effect, especially moral education based on the values of local wisdom of the Wonosobo community. The writer used the descriptive method in this study. Methods of data collection used the observation method (direct observation). The results of this study indicated that the cultural meanings implied in the mantra and sajen represented a harmonious relationship between humans and God, nature, themselves, and the surrounding community.
\end{abstract}

Keywords: Cultural meaning; social community; mantra; sajen

\section{Introduction}

Effendy stated that examples, verbal expressions, and behaviors that are used as examples used by the Malay to pass on the cultural values so that it will form a virtuous, intelligent, and have a commendable behaviour [1]. It represents that in addition to containing aesthetic values, oral literature is also loaded with various types of information related to the issue of cultural values owned by a social community that applies oral literature. These values are usually expressed implicitly or explicitly. Hanry Lanin stated that literary works, including oral literature, are a reflection of the expression of their social community [2]. One of the oral literature that is full of cultural values and we can find in the social life of society is mantra.

Mantra is the result of a culture of a social community that lives and develops in social life. Mantra is an oral literature that can be found in every social community in Indonesia, even the world and is considered something sacred so it cannot be spoken by any people, any time, and any place. Mantra has strength that cannot be measured by logic and is considered something that does not reason. This is because the spells is a sacred prayer that has supernatural powers that can make a one's hopes turn into something real. This is because the spell is a sacred prayer that has supernatural powers that can make a person's hope turn into something real. Spells in the form of wording are believed to be able to bring out magical powers if cast by 
someone who has mastered it [3]. Soedjino states that mantras cannot be read arbitrarily. The chanting of the mantra must meet the requirements of time, location, subject, speaker, equipment, clothing, and ordinance for telling it [4]. Related to this statement, Mulyanto argues that the nature of the spells (mantra) is sacred. The sacredness caused the convention that not everyone is allowed to recite the spell except pawang (the handler) [5].

The social community of spell owners believes that the magical power contained in the spell can be used as a means of control so that supernatural beings can be controlled, transformed, and ordered to do things aimed at achieving hope through rituals accompanied by offerings. In short, it can be said that the chanted mantras and the offerings presented in ritual ceremonies are used as media by humans to fulfill pragmatic and practical life goals. The ritual ceremony is a representation of the practice of the trust of a social community and cultural identity. This is in accordance with the statement of Koentjaraningkrat which states that religious elements in addition to being tangible as a community belief system in the idea of God, gods, spirits, and ancestors, these elements also take the form of ritual activities or traditional ceremonies that are seasonal or incidental [6]. Mulyanto states that there is a correlation between spell and religious attitudes or human beliefs. To interact with the creator, humans need a medium in the form of a series of words that have magical powers. That sequence of words is called mantra [5].

Traditional practices and rituals that make spells with magical nuances are still accepted by the people of Wonosobo. These traditions or rituals are passed down from generation to generation, getting recognition for their transmission and inheritance. This results in traditions or rituals with magical nuances still being carried out by the Wonosobo community and are considered as plays that will make hopes come true. For example, in the world of agriculture, planting rice, there are many ritualistic spells that must be carried out by the community so that the rice planted will bring abundant results. It is not just a hoax story. The people of Wonosobo have proven that the agricultural process accompanied by rituals with magical nuances will bring blessings to the perpetrators. Rice plants will be shunned by pests, rice plants will not be lost, and rice plants will produce abundant crops. This is because the ritual processes that are carried out and wrapped in mantras are full of benevolent values that make the process something that cannot be ignored (an interview with a farmer named Pak Cipto).

Based on the description, Wonosobo's agricultural spell became a very interesting thing to study. The rice planting mantra that is chanted at the time of wiwit is ripe. Ndaud, tandur, reject reinforcements, and harvest are full of aesthetic values and cultural values. In addition, the spells of the planting process in the agricultural procession are full of information that represents the cultural values possessed by a social community that can be used by researchers as a medium to understand culture in a social community. The problem that will be discussed in this research is what mantras are chanted by Selokromo farmers when they are active in agriculture, especially planting rice. In addition, it will also discuss what cultural values are represented in the chanted mantras.

Some of the reasons used by researchers as the reason for examining mantras in rice planting rituals are: 1) Wonosobo is a fertile area whose land is very suitable to be processed into agricultural land or plantations. Every farming or gardening activity in Wonosobo is accompanied by rituals that are full of magical nuances, 2) the number of people who have the competence to chant agricultural ritual spells is decreasing and their inheritance is not going well. Without research on this mantra, the mantra will not be well documented and will eventually become extinct, 3) Mantra is full of cultural values that have great benefits for the Selokromo people. Social phenomena that appear in the lives of the Selokromo people can be 
used as empirical evidence showing that mantras still have a very significant role and benefit in influencing the lives of the Selokromo people.

Talking about spells means talking about oral literature. Oral literature is used by the owner's community to express self-desire which is packaged using beautiful language and is full of meaning. Old poetry is one of the oral literature that is in great demand by the people of the past. This is evidenced by the emergence of various types of old poetry. Semi states that oral literature is a work that has existed since time immemorial. Even when the written tradition appears in the midst of society, oral literature still exists and can still be found in the social life of the people who own it [7]. Lord defines oral tradition as a spoken word. Therefore, the person who narrates does not translate it and the listener does not read it but listens [8]. Related to this, Danandjaja stated that oral literature, including spells, is a product of community culture that is widely spread and the inheritance is carried out from one generation to the next orally [9]. In line with this, Rusyana stated that a literary work produced by a community that is present survives even develops in spoken or unwritten form. Indonesia has an extraordinary wealth of oral literature [10]. Indonesia has an extraordinary wealth of oral literature.

One of the oral literature in the form of old poetry is rhythmic language. Alisjahbana states that mantra is a rhythmic language. Spell language has a strong and organized rhythm. The strength and regularity of the rhythm in the mantra is believed to bring out supernatural powers to help humans in achieving hope [11]. Furthermore, Djamaris stated that the mantra is in the form of a language composition that contains belief in the supernatural world and has supernatural powers. In the mantra, you will find a distinctive aesthetic of language, in the choice of diction, attention is paid to rhyme and rhythm, the essence is considered in depth. Malinowski states that the power of a mantra is centered on the utterance or chanting of the spell that is spoken. Casting spells is the core of performance magic [12]. Related to this, $\mathrm{T}$. Plattes states that etymologically the word mantra comes from Sanskrit 'mantra' or 'manir' which means sacred words. Mantras are usually cast for good purposes [13]. Sudjiman states that a spell contains a curse against supernatural powers. Mantras can also contain persuasion so that the supernatural powers that exist do not bring up things that are detrimental to humans. As word magic, mantras are chanted to gain power for the speaker [14]. Drajat stated that several factors cause the chanting of a spell. These factors are (1) as a thank you to the unseen for the blessings and safety that has been given; (2) an expression to convey a sense of belief in the occult; and (3) the existence of a desire to be achieved [15].

According to Waluyo, Spells can be identified through some characteristics (1) carefully selected diction; (2) sound repetition appears which has a function to increase the suggestion of the selected word; (3) the words are not straightforward; and (4) the words in the spell, if spoken aloud, will produce sound effects that give rise to supernatural powers [16].

Rusyana states that there are seven types of mantras that can be used as a medium to achieve a goal, namely jampe, asihan, singlar, jagjawokan, rajah, aji-ajian, and pellets [17]. Broadly speaking, the seven types of spells can be classified or grouped into two types of spells, namely black spells and white spells. White spells have goals that are oriented towards the power of spells that are believed to have a positive impact on spell users, namely to ward off wild animals, heal the sick, ward off and exorcise spirits, be loved by someone, be loved by someone, and spells that give rise to a mighty effect for the user. Black spells are spells that are believed to have a negative impact on someone being targeted or targeted, namely making someone suffer, get sick, and die.

The agricultural mantra, rice, is full of symbolic cultural meanings that express the local wisdom values of a social community that have been passed from one generation to the next. 
Rudiyanto states that cultural meaning in a tradition is usually symbolized verbally and nonverbally [18]. Furthermore Abdullah states that cultural meaning is the meaning of language that cannot be separated from the cultural context of the owner of the mantra which has a very strong correlation with the cognitive system, represented through the mindset, lifeview and worldview [18].

Ratna states that through intermediary media, humans can interact with supernatural beings who are believed to be ancestors. Therefore, an element that is no less important to complete the mantra is offerings which are better known as sajen [19]. Sajen became a medium of negotiation between the community and their ancestors. Sajen is served with the aim of seeking blessings or convenience in achieving the desired hope. Similar to mantras, offerings for people who still hold fast to and believe in them are considered to have sacred values that are full of local wisdom values. The value is usually represented by the symbols attached to the elements of the offerings presented. Each type of element contained in the offerings has a symbolic meaning. Turner states that "The symbol is the smallest unit of ritual which still retains specific properties of ritual behavior. It is the ultimate unit of specific structure in a ritual context"[20]. The symbol is the smallest element of a ritual ceremony that represents a meaning of the existing ritual activity that is special. Symbols are the main elements of a special structure in a ritual context that takes place [20]. Related to this, Koentjaraningrat has an idea that often the sesaji (everything that is used as sajen) offered to ancestors are only symbols whose interpretations arise from the community [21]. Zoest argues that a sign that refers to something real (denotatum) will lead to an interpretation of an object that is used as a symbol [22]. The offerings are arranged in such a way in one place and placed in places that are believed by the community to be sacred. Thus the pleasure of food from offerings will be felt by the spirits who guard these sacred places.

Several researchers have conducted research related to spells. However, researchers have not found any research that discusses the problem of agricultural mantras, starting from processing the land to harvesting, rice plants in the Selokromo Village area, Wonosobo. Several studies on mantras include those conducted by Jamilah and Fajarika Ramadania, entitled The Banjar Mantra Semiotic Study [23]. The study stated that the characteristics and functions of the Banjar mantra in South Kalimantan cannot be separated from the life of the people who own the mantra. Diction in spells is based on the purpose of the spell. This study only discusses the problem of features and forms. Cultural meaning is not touched in this research. Wardani, Nani Darmayanti, and Agus Nero Sofyan in their paper entitled The Function of Mantras in Jangjawokan: Ethnolinguistic Studies stated that people believe that the Jangjawokan mantra has magical powers [24]. The mantra has a function for the speaking community as a medium of self-expression, as a religion, and an expression of self-disclosure. This study also does not discuss the cultural meaning represented by the mantra. Nashichuddin et al. in his research entitled Meaning and Transmission of the Spirit-summoning Spell of Javanese Bantengan Arts in the Mburing Region of Malang, East Java, stated that the summoning spell has meaning and function in accordance with people's beliefs [25]. If used properly, the spell will have a positive impact on the social environment. The function of the mantra is to summon spirits to come and enter the dancer's body so that the dancer will be able to dance to the fullest. This research does not mention the cultural meaning of the mantra.

\section{Research Methods}


The method used in this research is descriptive method. The researcher will describe the cultural meaning contained in the data, both the meaning of the word or the meaning of the symbol. The data in this study was obtained with two techniques, namely the technique of observation and literature study techniques. The observation technique was carried out by going down to the research location and meeting several resource persons who had competence about the mantra of rice planting agriculture. Library study techniques are carried out by reading the literature in the form of previous research on spells. There are two data types in this study, namely verbal data and non-verbal data. Verbal data in the form of mantra utterances and non-verbal data in the form of symbols represented in offerings. The stages in this study were carried out by the following steps.

1. Looking for sources of data and information who have knowledge of rice farming mantras.

2. Perform data transcription. In this case, the researcher transcribed the recorded mantra utterance data.

3. Perform data transliteration. The researcher translated the transcription of data from Javanese into Indonesian. This is done to help make it easier to understand the contents of the mantra.

4. Interpret the data according to the problem raised. From the results of the transliteration, the researcher will interpret the cultural meaning that is represented from the data.

\section{Discussion}

Activities of farming are part of the culture and life of the Wonosobo community. Therefore to get maximum results and avoid pests, the Wonosobo community has a spell equipped with Sajen. These two things are used as a medium to express hope and desire in farming rice. In addition to expressing expectations, spells and sajen are also used as regular norms or behaviors in farming so that customs and cultural values can be maintained and inherited properly. Spells and Sajen are one of the media to achieve expectations in a Wonosobo community action or activity in farming. Mantras and offerings are full of cultural meaning as ancestral heritage.

\subsection{Cultural Elements and Meanings Contained in Sajen Rice Planting Activities}

Complementary spells that have a very significant role in the agricultural ritual ceremony are Sajen. Sajen implement how humans relate to their ancestors. With the ancestral offerings, they will feel happy so that the interaction between the community and their ancestors can be well and harmoniously established so that the ancestral spirits will assist humans in achieving the desired aspirations in a safe and peaceful state. On the other hand, if the offerings are not given in the farming ritual, the community believes that the farming activities carried out will not bring maximum results, and will even lead to danger and disaster. Each element of the offerings presented has a different meaning. Depending on the goals or aspirations desired by the giver of offerings. Related to this, Turner states that the offerings offered in ritual events are carried out as a form of negotiation in order to establish a harmonious relationship with ancestral spirits so as not to interfere with human activities [26]. The following elements and meanings of the Sajen are presented in each stage of farming activities carried out by the Selokromo village community.

\subsubsection{Wiwitan Macul}


Wiwitan macul is the initial process of cultivating rice fields for planting. Wiwitan macul is carried out as a process of reversing the soil so that the soil becomes fertile again. This is done because the surface of the soil in the fields is usually overgrown with weeds. When the soil is turned over, the weeds die and decompose. This is what makes the fields fertile. Wiwitan macul is done in the morning before sunrise. The initial ritual before wiwitan macul is the owner of the rice field circling his rice field 7 times. When circling the position of the left hand in the direction of the rice field, starting from the main water reservoir and returning to the starting point of the main water reservoir. After circling the rice fields, the owner of the field began to hoe seven times (pitung cowokan) as a sign that the field was ready to be worked on. The plowing is then continued by farm laborers who are involved in cultivating the fields.

The offerings given to ancestral spirits in the wiwitan macul stage are (1) flowers (red, white, ylang, and kantil flowers), (2) jajan pasar (enting-enting peanuts, jipang corn, and jipang rice), and (3) megana rice.

\subsubsection{Flowers}

Flowers presents a fragrant and fragrant aroma. This represents the relationship between humans and their ancestors harmoniously with the scent of flowers. It is believed by the Selokromo community that if a harmonious relationship is established, it will bring abundant blessings. Flowers served in the offerings are.

\section{a) Red roses}

Culturally, the color red symbolizes the love and courage that the owner of the field has for farmers. Farming requires courage, physical strength, tenacity, and a spirit not to give up or give up on all the risks that will be faced. Therefore, farmers must have courage and love for these things. Wiwitan macul a very heavy activity. It takes courage and strength to do this. The Selokromo people also identify the color red with protection. By presenting red roses in offerings to the ancestors, there is an interaction between the community and the ancestors. The hope is that the ancestors provide protection for the fields that are being cultivated. Protect rice fields from pests and natural disasters. Ancestral protection is expected to be present from the initial process to harvesting so that farming activities bring abundant results.

\section{b) White roses}

White is symbolized by purity, sincerity, sincerity of mind and heart of rice field owners and farm laborers in working on rice fields. Sincerely the owner of the field gives rights to the farm laborer and with good intentions the farmer helps the owner of the field by doing what is his obligation. A harmonious and well-established social interaction when each party (in this case the farmers and farm laborers) is aware of their respective rights and obligations sincerely and with a pure heart. In addition, the white color that appears in white roses represents freedom from evil intentions or violence. By presenting white roses, the community hopes that the ancestors will protect their rice plants so that they are protected from the evil intentions of other humans and are protected from the ferocity of rice pests.

\section{c) Kenanga}


This fragrant flower has a cultural meaning for the people of Selokromo, Wonosobo. This flower represents the ideals or achievement of hope to be addressed. The word anga which means goal and keno which means hit. In the Selokromo agricultural world, this flower represents the achievement of dreams in what kind of rice field cultivation is intended for. So that both farmers and farm laborers are aware of and know what to do to achieve the desired goals.

\section{d) Kantil}

In Javanese the word semrinthil means to follow. The philosophical meaning of this kantil flower refers to the meaning of the word semrinthil. The people of Seokromo believe that if they always try and pray, fortune will follow that effort and prayer. In wiwitan macul it takes a very hard effort. One of the determining factors for agricultural success is proper and proper land management. After wiwitan macul there are still several stages that must be done with hard work and prayer. Therefore, in the farming life of the Selokromo community, the jargon appears that kanthi behavior is kanthi laku tansah kumanthil which means that success can be achieved if there is effort and prayer.

\subsubsection{Jajan Pasar}

Jajan Pasar is a type of traditional snack food of a social community which is usually traded in traditional markets. This jajan pasar has various types and various flavors as well. The market snacks provided in the wiwitan macul offerings are enting-enting peanuts, jipang rice, and jipang glutinous rice. In the wiwitan macul event, jajan pasar are usually placed in one place to be served to ancestral spirits. The mixing of market snacks in one container represents a safe, peaceful, and peaceful life despite different religions, beliefs, and ethnic groups. To produce a large harvest, cultivating paddy fields does not need to question who owns the fields and who is the farm laborer. Each position has responsibility for the fields that are cultivated. There is no need to differentiate between rich and poor. The rich will not succeed without the poor (as farm laborers) and the farm laborers will not be able to work without the owners of the fields. In short, it can be said that the snack market represents harmony even though there are differences.

Snacks from the market also represent the meaning of aja kesasar. The meaning is in living human life not to get lost because of the inability to control lust. When the harvest is successful, farmers must be careful. Don't waste your harvest money. Use the harvest money for what is really needed.

\subsubsection{Megana Rice}

Megana Rice is white rice, grated coconut and seasonings. In serving megana rice is mixed with grated coconut and spices. The cultural meaning that emerges from these offerings is the spirit of sak merga-mergane ana, which means that everything needed is facilitated, provided, and fulfilled by the ancestors.

\subsubsection{Ndaut and Tandur}

Ndaut is a farming process that removes rice stalks that have been sown. The rice stalks that are sown are five-week-old rice seedlings planted in the nursery. The rice stalks that have 
been pulled out are then strung in large bundles using ropes made from the midrib of the banana tree trunk.

Ndaut is done in the morning. Before ndaut the owner of the rice field surrounds his field with incense, the path is from the right, the left hand leads to the inside of the rice field. The rice fields are surrounded by one bracelet meeting. After that, the ndaut seven pulls started, the left hand as the foundation of strength, and the right hand holding the sling and throwing it to the right. After that, the owner of the rice field starts the ndaut by sticking the dautan seven times from left to right, facing east, the direction of the rising sun. This represents a form of belief that the sun is the source of life for living things in this world. The offerings that are available when the ndaut event is held are:

\section{a) Nduwuran flower}

This offering consists of two flowers, namely red roses and white roses. Informant says Kembang nduwuran iku nduweni teges, disuwun marang sesepuh kang dadi piranti ALLAH, supaya parine dhuwur, panene dhuwur, regane pari ing tembe olih rega dhuwur. (The nduwuran flower has the meaning of asking God to make the ancestors as intermediaries so that the rice seeds planted will grow high, the harvest will be abundant, and the price of rice will later get a high price.)

The cultural meaning of this offering is the faith of the Selokromo community in Allah. Humans are creatures who have many shortcomings and become very weak creatures in front of Allah. Therefore, God becomes a place to beg and ask to realize that the harvest will be abundant and have a high selling value.

\section{b) Ombenan (drinks)}

Drinks in the form of tea, coffee, jumbawuk, and clear wedang or water. The drink shows that in life there are two sides that will come alternately, namely the sweetness of life and the bitterness of life. The emergence of a dark side that is synonymous with life's trials and a bright side that is synonymous with happiness. There is a dark side in humans and there is a white side in humans. These two things are complementary to humans in living life.

\section{c) Rice, Side Dishes, and Vegetables}

The rice is nasi olih, which is liwet rice topped with coconut milk. The word olih means can. Through these offerings, it is hoped that the hoe, the ndaut, the plant, and the harvest (olih) yield, the results obtained are abundant so that they can be taken home.

The side dish is tempe kemul, tahu bacem, tripe fish, and iwak so. Tempe kemul meaning as a sign that the start of the activity of planting rice seeds. Know what it means to work (farm labour) by tuhu (serious) in working, and following what and how the will of the owner of the field. Iwak babad has meaning a mbabadi which is dark, mbabadi which is a hindrance, mbabadi all pests so that the plants become healthy and produce a bountiful harvest. Iwak so has the meaning of working diligently, do not often ngaso (lots of rest). Ngaso (rest) sufficiently. If the energy has recovered immediately start working again.

The vegetables consist of two types, namely long beans and bobor godhong koro which means to be given patience in farming activities (long-suffering), not easily angry, and not stagnant, not growing, or easily discouraged (bobor) in an attempt to obtain a bountiful harvest. 
After the ndaut is completed the next stage is tandur or planting rice. The right technique for planting rice seeds is needed to avoid obstacles that will harm farmers. Therefore, it is necessary to have a code of conduct that is usually done by the ancestors in planting rice seeds. The Selokromo people begin the tandur process by facing the direction of the rising sun, which is east and retreating to the west. This represents a living belief that the sun is the source of life. Oleh karena itu matahari jangan diungkurke (dibelakangi). The benefit that will be obtained by this practice is that the rice plant will live, develop, and produce an abundant harvest, just as the rising sun provides a source or benefit for all living things in this world. Walking backwards and facing the sun has a philosophical meaning that shows a form of respect for the sun as the source of life.

\subsubsection{Maintenance}

After the seeds are planted, the next stage is maintenance or care. Protecting rice fields from pests and keeping rice fields waterlogged is a challenge for farmers. So that pests do not attack plants and there is no shortage of water, a ritual must be carried out by Selokromo farmers to ward off pests and irrigate the fields. Rituals for maintaining rice plants and irrigating rice fields are usually carried out at dusk until the evening. This is because if the irrigation process is carried out in the morning or afternoon, the rice plants will wither and eventually die. Water is usually taken from the flow of river water around the rice fields.

Irrigating rice fields and protecting them from pests for Selokromo farmers cannot be done haphazardly. The best days to irrigate the rice fields are Tuesday Kliwon, Friday Kliwon, and every Friday night. According to Javanese calculations, the Selokromo people believe that Tuesday Kliwon, Friday Kliwon has a jenjem gede/jenjem duwur coun $\mathrm{t}$ (has a high number of counts compared to the number of other days). This implies that the duwur or fast-growing rice plant can produce a large or abundant harvest.

The behavior is carried out, the owner of the rice field surrounds the rice field at 21.00 or 00.00 naked. Step to the right, the left hand is in the direction of the rice field. The symbolic meaning of being naked is to let go of all lust and be clean from worldly affairs. Man is holy at first born. He did not carry anything from his mother's womb. This holiness will later become a support for the granting of prayers that are said through mantras. The symbol of the left hand is in the direction of the rice field because the direction of the water flows to the left. Why not the right hand that goes into the rice field? because it has the meaning of stemming water. It is not good. If the water is dammed, then the water will not flow and remember the fields.

Water is the source of plant life. River water used to irrigate rice fields is flowing river water. It has a symbol of noble character values. Running water will be able to wash away the dirty to be clean and carry the dirt carried away by the current. It carries the sense that harmful things, pests, are expected to be kept out of rice fields and produce abundant harvests. The flowing water also represents that life will go on walking as the flowing water does. Never go against the current and never go into the current to get swept away. The farming business must never end in the middle of the road. Follow the rules so it brings a blessing. Follow the flow of water by staying awake so that the feeling becomes something real. In this case business must be kept as water flows to a standstill at the estuary, which means that farming must be kept viable until the produce has been abundant.

\subsubsection{Harvest}


After four months, the rice turns yellow. In terms of age, rice is ready to be harvested. Selokromo people use sickle or ani-ani to cut rice plants. Harvest stages also cannot be done haphazardly. There is a ritual of chanting spells and sajen (offering) as a form of gratitude to the ancestors for having bestowed fortune in the form of rice harvests to farmers. The ritual behavior begins with the preparation of sajen. Before harvesting is done, farmers burn incense in every corner of the rice fields, surround them, and chant spell in every corner of the fields as a form of requesting permission to the ancestors that rice picking will begin soon. Picking rice begins with the owner of the field picking 7 times. The rice that is picked is not just any rice, but the best rice (the informant said of the thousands of plants that exist, there are several rice plants that emit light and that is the best rice that will be picked first). The rice that emits the light will be made up and used as rice bride. The rice is the first to be brought home and dressed like a bride. Rice is dressed up by wearing a kebaya and jarik. When bringing home the best choice of rice, the bearer must not shift or change the position of the bearer. When the pole is placed on the right shoulder, the bearer may not move the pole to the left when bringing the selected rice home. This represents a strong and consistent attitude towards the choice to become a farmer. How heavy the burden is carried is a responsibility that must be carried out and should not be handed over to other parties. Or in other words, you can't run away from your responsibilities. Then the selected rice will be handed over to the village elders who have the longest farming experience. Or the selected rice can be handed over to Mbah Glondong or the village head.

The offerings used to complete the chanting of the spells in the harvest event consist of flowers, food, and drinks. The offerings served are not just food. The food in the offerings that are served represents the values of wisdom that are very high in value. The offerings are presented as follows.

\subsubsection{Flower}

The flowers served are nduwuran flowers, telon flowers, fragrant flowers, and kinag..

\section{a) Nduwuran Flower}

Nduwuran flower (duwur is javanese word means high). This flower offering consists of two types of flowers, namely red roses and white roses. The philosophy meaning of the nduwuran flower is so that the rice harvest gets high income (duwur). Abundant results obtained and (duwur) high selling price.

\section{b) Telon Flower}

Telon comes from the word telu (three). Telon flower is a group of flowers consisting of three types of flowers, namely roses, kantil flowers, and jasmine flowers. Roses have the meaning of everything that is bad immediately go away, the ability to control oneself patiently. Kantil flower has the meaning of laku tansah kumantil, which means that with effort, results will be attached. Kenongo has the meaning tumengo which means having the soul to help each other, having social sensitivity to the surrounding conditions. With telon flowers, the hope to be achieved is to avoid calamity, productive efforts, and sensitive to the conditions or circumstances of fellow human beings. In this farming activity, the three flowers represent the hope that rice plants will be protected from pests, farming activities that are full 
of effort produce abundant harvests, and some of the agricultural produce is used to give charity by helping neighbors who are in need.

\section{c) Fragrant Flower}

Fragrant flowers are a group of flowers that give rise to a fragrant aroma. This fragrant flower offering consists of red roses, white roses, kantil, ylang, and sliced pandan. Fragrant flowers represent a hope that the rice from the harvested rice will smell good when cooked. In addition, it also means that rice plants are free from walangsangit pests. The aroma that is associated with the walangsangit pest will disappear with the fragrance that appears in the offerings.

\section{d) Kinang Sih}

This offering consists of betel leaf, apu/injet (chalk powder), gambier, and jambe. The four elements of quinang have different colors. However, if all these elements are put together, it will produce the same color, namely dubang (idu abang,it means red saliva). Kinang still has the meaning of Dewi Sri asiha welasa marang bapak dan simbok tani which means that Dewi Sri bestows her affection on the farmers by bestowing abundant harvests. In addition, this offering also has a cultural meaning that human life in the world is of various kinds and colors. To be able to meet their needs, humans cannot stand alone. Humans complement each other from one element to another. The combination of these various elements will produce something new, namely tepo sliro (mutual respect). Therefore, rice field owners and farm laborers are an inseparable element and have a symbiotic nature of mutualism. Rice field owners and farm laborers are teamwork that brings success or fruitfulness in farming.

\subsubsection{Food}

The food served to complement the offerings is usually food in the form of traditional market snacks consisting of roasted sweet potato, jipang enting,rice jipang,corn jipang , megana rice. Kinangsih, Ingkung. Each type of snack has a cultural meaning associated with farming activities. The following is the meaning of snacks included in the offerings.

a. Sweet potato roasted is a typical food in Selokromo Village. This dish is made from roasted sweet potatoes. The expression sak budine nggayuh panenan means what is cultivated to get an abundant harvest. A form of communication addressed to God in the form of a hope or request so that what is planted produces maximum results.

b. Krambil Golong is a burnt coconut. Coconut as a symbol of the results of an effort (the fruit) and the real purity (the water). This offering symbolizes a hope that what is produced in a form of effort that is carried out in a pure and sincere manner is collected in the hands and does not run out in vain (mbengkat). This implies that life does not waste money as one of the lifestyles of the people of Selokromo Village so that the results of the hard work carried out through farming activities do not run out in vain.

c. Jipang enting symbolizes that what is produced will be collected (diunting). It has the same meaning as krambil golong.

d. Rice jipang symbolizes that those who harvest (field owners) and those who help harvest (farmers) get healthy (waras). A hope that Health becomes the main thing. Harvesting can be done if the rice field owners and farm laborers are given health, both physical and psychological health. Psychologically helathy means that the parties involved in farming 
activities must be aware of their rights and obligations. Should not be jealous of the distribution of the harvest because the results of the distribution of the harvest are adjusted to the rights and obligations of the owner of the fields and the laborers of the fields

e. Corn jipang symbolizes a hope that the harvest will be ngundhung-ngundhung (producing abundant yields). A hope and a request addressed to the ancestors so that later the rice plant will produce abundant harvests.

f. Megana rice Megana rice has the meaning of sak merga-mergane ana which means that whatever effort has been made in farming, it is always fulfilled. Allah provides for the seeds, fertilizers, water, energy, and costs. Thus, farming activities carried out by the people of Selokromo Village will run smoothly and will not stop in the middle of the process due to a lack of something.

g. Ulamsari is ingkung chicken, which is a whole chicken that is cooked and served whole along with the innards in a prone position. This offering is etymologically derived from the Old Javanese language jinangkung and menekung have the meaning of 'protect' and 'to pray'. Allah is the source of love and protection. Therefore, it is an obligation for humans as His creatures to seek protection and kneel to Him as a form of faith and piety. In farming activities this must be done. By kneeling and asking God for safety, the rice seeds planted will grow into fertile rice plants and produce abundant harvests so that it will bring blessings, health, happiness, and safety together.

\subsubsection{Degan Ijo (Young Green Coconut Drink)}

The drink served at the rice harvest event is degan ijo (young coconut of the type of green coconut). The people of Selokromo Village believe that by symbolizing prosperity and usefulness. Farming has many functions or benefits for the people of Selokromo Village. As with every element of the part has benefits for humans. With farming activities, the people of Selokroma Village will become prosperous.

\subsection{Cultural Meanings Contained in the spell of Rice Planting Activities}

The rice planting ritual ceremony cannot be separated from the spells that are believed by the people of Selokromo Village as a form of supplication and thanksgiving for the generosity of the ruler of nature who has given them the pleasure of farming which has a very important role in life. Ritual ceremonies are carried out based on local customs or customs as ancestral heritage. This is what makes the people of Selokromo Village, especially farmers, treat farming activities not carelessly. The recitation spell ritual is performed at the time of macul wiwitan, macul, ndaut, ngopeni, until harvest. Koentjaraningrat states that ancestral heritage is a system of cultural values in the form of concepts of human thought that existed in an era [27]. The value system that becomes the ancestral heritage has a very high value, is valuable, and becomes something very important that can be used as a basis or guideline for people's lives.

Rituals that appear in the farming process in Selokromo Village, Wonosobo include four phases, namely the initial phase (wiwitan macul), ndaut, tandur, ngopeni, and manen(harvesting). The following will describe the cultural meaning contained in the spell of each phase.

\subsubsection{The Wiwit Macul Mantra is As Follows}


Bapa Biyung sekti, jabang bayi pulih wingi, aku njaluk tulung, iki sesajining rakan sing mbahu rekso sawah.....(jeneng sing duwe sawah).

Ladies and gentlemen who are really powerful, the baby recovered yesterday, I ask for help, this is the complete offering that controls the rice fields.....(name of the owner of the rice fields)

There is harmonious communication between the people of Selokromo Village and their ancestors. This harmony is represented in the act of giving and receiving. The sentence aku njaluk tulung, iki sesajining rakan sing mbahu rekso sawah....from this spell, it represents an attitude that is not only asking, but also trying to achieve the hope (by giving offerings) what you want. There is a negotiation process between ancestors and descendants in farming.

\subsubsection{Ndaut and Tandur}

The spell that is chanted at the time of ndaut and tandur is as follows:

Assalamu'alaikum..

Bapak tani biyung tani aku arep wiwit daut

Ingkang didaut ingkang daut

Ndang waraso, ndang slameto

Waras..waras..waras seko pitulunganing gusti

Daut sampun rampung, kulo ajeng mbanjari

Bismilahirahmanirahim...

Assalamualaikum..

Mr. and Mrs. farmer, I will start pulling or moving rice seedlings to the fields

(rice seeds) that are uprooted and (people) who pluck

Be healthy and safe

Healthy...healthy...healthy...because of God's help.

Unplug the rice seeds is finished, I will line my fields

The spell that is chanted at the time of nandur is as follow:

Bismilahirahmanirahim

Sun arep lungguhe bumi tuo

Kawula nyuwun seko pangucape poro manungso

Dipun sekseni poro nabi lan poro wali

Lan dipun sekseni bumi langit sakisine

Dupo jowo asline ing tanah jowo

Kawulo nyuwun kramate sing mbaurekso sawah kubang kene

Sirruloh dattuloh, badan jasmani rohmani

Kulite, balunge, wadake, aku iki manungso

Aku arep wiwit tandur

Ingkang nandur ingkang tinandur, ndang waraso

Ing dino kamis pon jenjem pitulas

Bismilahirahmanirahim

I will sit on this old earth

I ask from the words of humans

What the prophets and saints witnessed

And witnessed by the earth, the sky, and all that is in it Javanese incense originally

from the land of Java

I ask the ancestors who controlled the fields and

springs here 
Sirruloh dattuloh, spiritual body

The skin, the bones, and the place, I am human

I will start planting

Those who plant, what is planted, get well soon

On Pon jenjem Thursday seventeen

The two spells represent politeness in behaving or acting. The value of mutual respect between one creature and another, including living and supernatural beings. The sentence Bapak tani biyung tani aku arep wiwit daud. Kawulo nyuwun kramate sing mbaurekso sawah kubang kene implicitly contains information as well as asking for permission from bapak tani biyung tani who symbolizes the goddess of fertility, namely Dewi Sri to start ndaut activities. In the world of agriculture, Dewi Sri is believed to be a figure who presents rice plants in the world [28]. The purpose of chanting the ndaut spell is worship and a request to get the gift of health so that farming activities will run smoothly and not be obstructed.

The spell also represents the value of respect for everything that is created by God. Therefore, the sentences Ingkang nandur ingkang tinandur, ndang waraso represent an attitude of respect and belonging between humans and nature so that praying for each other for safety is a manifestation of that feeling. Maintain and protect the relationship each other between nature and humans is a symbiotic relationship of mutualism. Nature is maintained by humans and nature provides all human needs.

Ing dino kamis pon jenjem pitulas represents that the life of the people of Selokromo Village does not forget the teachings of science from their ancestors. Dino Kamis, Pon Jenjem Pitulas, showed that in petungan farming activities, or counting the days, the community has never abandoned it. The community believes that if they do not violate petungan, farming activities will be smooth, far from disaster, and will produce blessings. On the other hand, if petungan is violated or even abandoned, the disaster will be reaped from farming activities. This belief has been going on for hundreds or even thousands of years. The method used is the ngelmu titen method which means it is based on life experiences that have been lived and faced by the communityt.community.

\subsubsection{The spell of Ngopeni}

The spell that is chanted at the time of ngopeni is as follow Ono kidung sawabe poro nabi lan poro wali

Nabi adam, nabi idris, nabi nuh, nabi husholeh, nabi Ibrahim, nabi lut, nabi ismail, nabi isha, nabi yakub, nabi yusuf, nabi ayub, nabi sungaib, nabi harun, nabi musa, nabi zulkifli, nabi daud, nabi sulaiman, nabi yahya, nabi yakaria, nabi isa, nabi Muhammad. Kanjeng nabi sampun dawuh ken sabar

Berkat malaikat kawan doso sekawan, kalih walisongo

Kanjeng sunan kalijogo ingkang rumekso banyu putih

Kanggo tetombo awak, kanggo tetombo leloro

Lir ilir, llir ilir

Tandurane ndang cepet nglilir

Lir ilir, lir ilir

Ono moro beboyo, ndang singkirno saka sawah kene

Lir ilir lir ilir

Ono hama tikus, hama wereng, ndang singkirno

Lir ilir lir ilir 
Hama tikus seko wetan, hama tikus kulon

Ono hama tikus seko kidul, ono hama tikus seko lor

Ndang singkirno ndang sirnakno

Lir ilir lir ilir

Ono hama wereng . ono hama walang ketege

Ono lembing yo ndang singkirno, yon dang sirnakno

Waras...waras...waras seko pitulunganing gusti

There is a song containing the truth from the prophets and saints Prophet Adam, Prophet Idris, Prophet Nuh, Prophet Husholeh, Prophet Ibrahim, Prophet Lut, Prophet Ismail, Prophet Isha, Prophet Yakub, Prophet Yusuf, Prophet Ayub, Nabi Sungaib, Prophet Harun, Prophet Musa, Prophet Zulkifli, Prophet Daud, Prophet Sulaiman , Prophet Yahya, Prophet Yakaria, Prophet Isa, Prophet Muhammad.

(the prophet ordered to be patient)

(Blessings of 44 angels and wali songo)

( Sunan Kalijaga who guards the water)

(As body medicine, for the disease medicine)

Lir ilir, lir ilir

(let the plant grow fast)

Lir ilir, lir ilir

(There is a danger, immediately expel from the fields here) Lir ilir, lir ilir

(There are rat pests, planthoppers, get rid of them immediately)

lir lir lir lir

(Eastern rat pest, southern rat pest)

(There are rats from the West, there are rats from the north) (get rid of it immediately, get rid of it immediately)

lir lir lir lir

(there are planthoppers. There are grasshoppers Ketege) (there is a bug, so get rid of it immediately, get rid of it immediately) (healthy...healthy....healthy from God's help).

The spell is sung as an expression of gratitude to Allah along with His prophets and guardians who have bestowed, maintains the fertility of agricultural crops, and protects them from pests that can harm farmers. The word lir-ilir in the spell, which is duplicated five times, shows how important it is. The word lir-ilir etymologically comes from the word nglilir which means to wake up or be awake. Protected from laziness, complacency, and arrogance. So that farmers are aware that the rice seeds planted need to be protected from things that will harm farmers, in this case are pests, and take care of them by providing adequate irrigation so that the plants thrive and produce abundant results. Therefore, farmers must be awake from laziness to care for and maintain their plants so that the tandurane ndang cepet nglilir (the plants protected and grow fastly.

In addition, the chanted spell also represents the faith of the people of Selokromo Village towards Allah, prophets, and saints who have provided sufficient water to irrigate their fields. The opening sentence of the mantra Ono kidung sawabe poro nabi lan poro wali represents that Allah, prophets, and wali(saints) are the bearers of truth. This is not doubted by the people of Selokromo Village so they must be quickly protected from traits that can harm themselves. Hard work and tenacity in farming will make the plants grow quickly and fertile in tandurane ndang cepet nglilir. In addition, they are awake and responsive to conditions that will bring good to the farmers. Respond quickly if their fields are in danger so as soon as possible take action to save the rice planted in their fields. Ono hama wereng. Ono hama walang ketege. Ono lembing yo ndang singkirno, yon dang sirnakno. Protected from the nature of arrogance 
because humans are weak creatures. All successes and successes achieved by humans cannot be separated from the will and help of Allah, Waras...waras...waras seko pitulunganing gusti.

\subsubsection{The spell of Manen}

The following is a spell that is chanted when burning incense as the beginning of the rice harvest ritual.

Dupo jowo asline ing Tanah Jowo

Kulo nyuwun keramate kang mbahu rekso sawah........(jenenge sing duwe sawah)

Blegere, wadage aku iki manungsa

Klengkeng jati arane menyan

Surya jati urube menyan

Sunan Gunung Jati tak jaluk gawene

Nyuwunake kalih Gusti Allah kang Maha Agung

Maha Welas, lan Maha Asih

The original Javanese incense from the land of Java

I ask for the sacred who controls the rice fields....(say the name of the owner of the rice fields)

My form, my birth is a human body

Klengkeng jati the name of this incense

Sunan Gunung Jati, I beg your help

Praying to the Almighty God

Most Compassionate, and Most Merciful.

God is the source of all sources of help. The people of Selokromo Village realize that they are human beings created by God who have many weaknesses and shortcomings. This confession is represented in the Blegere spell, wadage aku iki manungsa. The sentence Nyuwunake kalih Gusti Allah kang Maha Agung Maha Agung Maha Welas, lan Maha Asih represents a value that the people of Selokromo Village believe in and always have hope and ask God for help. This is done because people believe that God is Most Great, Most Compassionate, and Most Merciful. The ritual is a manifestation of a behavior that expresses the love of the Selokromo Village community for God. Such behavior shows that the people of Selokromo Village are religious behavior. Represented the expression of a social system that shows the relationship of the people of Selokromo Village with their spiritual nature. The relationship between worldly life and the life of belief, the relationship between posterity and their ancestors.

\section{Conclusion}

Farming activities carried out by the people of Selokromo Village are broadly divided into four parts, namely wiwitan macul, ndaut and nandur, ngopeni, and manen. In each section performed with rituals and chanting spells accompanied by offerings. This is done with the aim of building good communication between the community and their ancestors. The offerings served as a complement to the spell in farming rituals carried out by the people of Selokromo Village, Wonosobo are full of cultural meaning. Spells and offerings are used as a medium to establish a good communication relationship with the ancestors. Through offerings and mantras, hopes and requests are manifested to the ancestors to give success in farming activities. 
The values contained in spells and offerings can be grouped into four interactions between humans and the supernatural. The four interactions that have been identified are.

1. Interaction with God, manifested in the form of thanksgiving, worship, requests for salvation, health, and success or success.

2. Interaction with nature.

3. Interaction with oneself, manifested in values for being diligent, persistent, tenacious, working hard, not easily discouraged, not wasteful, and not arrogant.

4. Interaction with the community, manifested in the values of mutual respect, appreciation, and mutual assistance between one human being and another.

\section{References}

[1] Nisdawati, "Nilai-Nilai dalam Teks Cerita Panglimo Awang pada Tradisi Bukoba Masyarakat Melayu Pasir Pengaraian Sebagai Bahan Ajar Bahasa Indonesia," J. Ilm. Edu Res., vol. 4, no. 1, pp. 9-20, 2015.

[2] H. Wua, "Bentuk dan Makna Tuturan Kabhanti Manari pada Masyarakat Muna," $J$. Humanika, vol. 3, no. 15, 2015.

[3] M. Mansur, Dahsyatnya Berobat dengan Al-fatihah. Yogyakarta: Araska, 2010.

[4] Soedjino and dkk, Struktur dan Isi Mantra Bahasa Jawa di Jawa Timur. Jakarta: Departemen Pendidikan dan Kebudayaan, 1987.

[5] E. S. Mulyanto, "BENTUK DAN FUNGSI TEKS MANTRA," Kadera Bhs., vol. 9, no. 2, pp. 75-87, 2017, doi: https://doi.org/10.47541/kaba.v9i2.7.

[6] Koentjaraningrat, Manusia dan Kebudayaan Indonesia. Jakarta: Djambatan, 1990.

[7] A. Semi, Metode Penelitian Sastra. Bandung: Angkasa Bandung, 1993.

[8] Lord. Albert B., The Singer Resumes The Tale. London: Cornell University Press, 1995.

[9] J. Danandjaja, "Pendekatan Folklor dalam Penelitian Bahan-Bahan Tradisi Lisan," in Metodologi Kajian Tradisi Lisan, Jakarta: Asosiasi Tradisi Lisan, 2008.

[10] L. P. dan B. I. Rustanti, "Ajaran dan Pemikiran Sunan Kalijaga pada Legenda Penamaan Desa di Masyarakat Demak," Seloka J. Pendidik. Bhs. dan Sastra Indones., vol. 6, no. 3, pp. 265-272, 2017, doi: 10.15294/SELOKA.V6I3.20256.

[11] Alisjahbana, Puisi Lama. Jakarta: Dian Rakyat, 1975.

[12] B. Malinowski, Magic, Science and Religion and Other Essays with an Introduction. New York: Doubleday Anchor Book, 1955.

[13] H. Daud, Ulit Mayang: Kumpulan Mantra Melayu, 1st ed. Selangor: Dawama Sdn.Bhd, 2004.

[14] P. Sudjiman, Kamus Istilah Sastra. Jakarta: UI Press, 1990.

[15] Drajat, Ilmu Pendidikan Islam. Jakarta: Bumi Aksara, 1996.

[16] H. J. Waluyo, Pengkajian dan Apresiasi Puisi. Salatiga: Widyasari Press, 2010.

[17] H. Aswad, Nurhayaty, and I. Said, "The Use of Mantra in the Tradition of Maitai Allo Macoa in Onglo People Campalagian Subdistrict Polman Regency: a Review of the Semiotics," J. Ilmu Budaya, vol. 6, no. 1, pp. 143-153, 2018, doi: https://doi.org/10.34050/jib.v6i1.4319.

[18] Rudiyanto, Wakit Abdullah Rais, and D. Purnanto, "Tinjauan Etnolinguistik: Makna Kultural dalam Tradisi 'Sranan' sebagai Wujud Kearifan Lokal Masyarakat Petani Pegunungan di Kebumen," in Prosiding Seminar Nasional Linguistik dan Sastra (SEMANTIKS) 2020, 2020, pp. 543-552. 
[19] N. K. Ratna, Teori, Metode, dan Teknik Penelitian Sastra, 11th ed. Yogyakarta: Pustaka Pelajar, 2012.

[20] N. W. Sartini, "Makna Simbolik Bahasa Ritual Pertanian Masyarakat Bali," J. Kaji. Bali, vol. 07, no. 02, pp. 99-120, 2017, doi: https://doi.org/10.24843/JKB.2017.v07.i02.p06.

[21] Koentjaraningrat, Beberapa Pokok Antropologi Sosial. Jakarta: Dian Rakyat, 1992.

[22] A. Van Zoest, Fiksi dan Nonfiksi dalam Kajian Semiotik. Jakarta: Intermasa, 1991.

[23] Jamilah and Fajarika Ramadania, "Kajian Semiotik Mantra Banjar," Tarb. J. Ilm. Kependidikan Off. Fak. Tarb. dan Kegur., vol. 7, no. 1, pp. 51-57, 2018, doi: http://dx.doi.org/10.18592/tarbiyah.v7i1.2101.

[24] A. P. Wardani, Nani Darmayanti, and Agus Nero Sofyan, "Fungsi Mantra dalam Jangjawokan: Kajian Etnolinguistik," J. Metabasa, vol. 2, no. 2, pp. 55-63, 2020.

[25] M. Nashichuddin, Muhammad Gibravil Rifki, and P. L. P., "Makna dan Transmisi Mantra Pemanggilan Arwah Kesenian Jawa Bantengan Daerah Mburing Malang Jawa Timur," J. Pendidik. Bhs. Indones., vol. 6, no. 1, pp. 57-64, 2018, doi: http://dx.doi.org/10.30659/j.6.1.57-64.

[26] A. Ismail, Agama Nelayan: Pergumulan Islam dengan Budaya Lokal. Yogyakarta: Pustaka Pelajar, 2012.

[27] Koentjaraningrat, Pengantar Ilmu Antropologi. Jakarta: PT Rineka Cipta, 1979.

[28] I. N. Suaka, "Folklor Bhatari Sri Kearifan Lokal Petani di Balik Warisan Budaya Dunia," in Folklor dan Folklife dalam Kehidupan Modern, S. Endraswara and dkk, Eds. Yogyakarta: Ombak, 2013.

[29] Sucipto, a resident of Selokromo Village, District of Leksana, Wonosobo Regency. The interview was held on March 7, 2021 at 19.30 (West Indonesia time standard). and March 8, 2021 at 20.00 (West Indonesia time standard).

[30] Winarni, a resident of Selokromo Village, District of Leksana, Wonosobo Regency. Interview was conducted on March 8, 2021 at 10.00 (West Indonesia time standard). 